\title{
Evaluation of Fenton oxidation process coupled with biological treatment for the removal of reactive black 5 from aqueous solution
}

\author{
Pegah Bahmani ${ }^{1}$, Roshanak Rezaei Kalantary ${ }^{1,2^{*}}$, Ali Esrafilii, Mitra Gholami ${ }^{1,2}$ and Ahmad Jonidi Jafari ${ }^{3}$
}

\begin{abstract}
Biodegradation of azo dyes is difficult due to their complex structures and low BOD to COD ratios. In the present study, the efficiency of using Fenton's reagent $\left(\mathrm{H}_{2} \mathrm{O}_{2}+\mathrm{Fe}^{2+}\right)$ as a pretreatment process to enhance microbial transformation of reactive black 5 (RB5) in an aqueous system was evaluated. The RB5 with an initial concentration of $250 \mathrm{mg} / \mathrm{L}$ was decolorized up to $90 \%$ in $60 \mathrm{~h}$ by using a bacterial consortium. Fenton's reagent at a Fe ${ }^{2+}$ concentration of $0.5 \mathrm{mM}$ and $\mathrm{H}_{2} \mathrm{O}_{2}$ concentration of $2.9 \mathrm{mM}$ (molar ratio, 1:5.8) was most effective for decolorization at $\mathrm{pH}=3.0$. The extent of RB5 removal by the combined Fenton-biotreatment was about 2 times higher than that of biotreatment alone. The production of some aromatic amines intermediates implied partial mineralization of the RB5 in Fenton treatment alone; in addition, decreasing of GC-MS peaks suggested that dearomatization occurred in Fenton-biological process. Fenton pretreatment seems to be a cost-effective option for the biotreatment of azo dyes, due mainly to the lower doses of chemicals, lower sludge generation, and saving of time. Our results demonstrated positive effects of inoculating bacterial consortium which was capable of dye biodegradation with a Fenton's pretreatment step as well as the benefits of low time required for the biological process. In addition, the potential of field performance of Fenton-biological process because of using bacterial consortium is an other positive effect of it.
\end{abstract}

Keywords: Fenton oxidation process, Anoxic biological treatment, Decolorization, Mineralization, Azo dyes

\section{Introduction}

Textile industries produce large amounts of liquid effluents. More than $7 \times 10^{5}$ tones of synthetic dyes are produced annually by textile industries [1,2], of which $2.8 \times 10^{5}$ tones are discharged [3-5]. Azo dyes belong to the largest and most versatile class of dyes [6] and present about $60-70 \%$ of dye stuff released into the environment [7]. Discharge of wastewater containing azo dyes results in the pollution of aquatic systems and, therefore, causes adverse effects on human health [8]. Generally, most of these dyes or their cleavage products (i.e., aromatic amines) may be mutagen or carcinogen [9-11]. Hence, treatment of wastewater containing such dyes is essential to prevent deterioration of ecosystems $[12,13]$.

\footnotetext{
* Correspondence: r-rezaei@tums.ac.ir

${ }^{1}$ Department of Environmental Health Engineering, School of Public Health,

Tehran University of Medical Sciences, Tehran, Iran

${ }^{2}$ Center for Water Quality Research (CWQR), Institute for Environmental

Research (IER), Tehran University of Medical Sciences, Tehran, Iran

Full list of author information is available at the end of the article
}

Previous studies have shown that the physicochemical methods of treatment (i.e., adsorption, ozonation, and advanced photochemical oxidation) have been applied for the treatment of the effluents [14-17]. However, these processes have achieved limited success because they are associated with the generation of large amounts of sludge, which is difficult to dispose [18], or may cause secondary pollution due to the use of excess chemical materials [13]. Although biological treatment is a wellestablished, cost-effective technology, it has been proven inefficient for the degradation of azo dyes like Reactive Black 5 (RB5). This is due primarily to the fact that they have nitrogen to nitrogen double bonds $(-\mathrm{N}=\mathrm{N}-)$, aromatic rings, and low BOD to COD ratios $(<0.1)$ [19].

Due to the combination of both environmental and economic advantages, the coupling between chemical and biological processes can be a suitable solution for the removal of toxic compounds from aqueous medium [20-22]. Advanced oxidation processes (AOPs) such as 
Fenton reagents $\left(\mathrm{H}_{2} \mathrm{O}_{2} / \mathrm{Fe}^{2+}\right)$ may improve the biodegradability of synthetic dyes through the use of shortlived, highly reactive hydroxyl radicals $(\mathrm{OH} \bullet)[23,24]$. Moreover, Fenton oxidant is commercially available and easy to handle environmentally. In most cases, Fenton is used for both decolorization and mineralization simultaneously; thus higher doses of $\mathrm{H}_{2} \mathrm{O}_{2}$ and $\mathrm{Fe}^{2+}$ ions are required. However, smaller amounts of Fenton reagents are required when combined with biological processes. Lucas et al. (2007) showed that C. Oleophila as a pure culture had a good efficiency in degradation of the dye after Fenton process [25]. Decolorization of Reactive Red 2 by Pseudomonas sp. SUK1 showed that the acclimated pure bacteria have better efficiency for dye removal than an acclimated consortium of the bacteria [18]. Usually the effect of pure culture is more than that of mixed culture; however, since the maintenance of pure culture in the environment is not easy, the utilization of a consortium of the microorganism is preferable [1]. Mohana et al. (2008) used a novel bacterial consortium for decolorization of Direct Black 22 [12].

In this study, the Fenton oxidation process was used prior to biodegradation for breaking the unsaturated bonds $(-\mathrm{N}=\mathrm{N}-)$ of RB5. Furthermore, degradation can be achieved by a consortium of acclimated bacteria. The combined Fenton oxidation/bioreactor process is expected to be more economical and effective compared to any single treatment technology for the treatment of RB5. Because of using bacterial consortium which had not been used before in such coupled process, the Fenton-biological process has the potential of field performance.

Therefore, the aim of the present study was to investigate the Fenton oxidation process to achieve complete decolorization of RB5 and partial cleavage of aromatic amines to make them easily biodegradable by a bacterial consortium.

\section{Material and methods}

\section{Chemicals}

Commercial grade RB5 (as a model dye) was purchased from Alvan Sabet Company (Hamedan, Iran) and used without any further purification. Figure 1 shows the structure of RB5. A stock solution of the dye $(1000 \mathrm{mg} / \mathrm{L})$ was prepared in distilled water and used for all experiments. Dichloromethane, acetone, and methanol were supplied in HPLC grade by Merck, Germany. Analytical grade chemicals used for mineral salt medium (MSM) as well as culture media were purchased from Merck Company.

Ferrous sulfate hepta hydrate $\left(\mathrm{FeSO}_{4} \cdot 7 \mathrm{H}_{2} \mathrm{O}\right)$ was used as the source of $\mathrm{Fe}^{2+}$ catalyst in the Fenton process. Hydrogen peroxide solution (30\%, w/w), sulfuric acid, and sodium hydroxide were also purchased from Merck Company. All of these chemicals were of analytical grade.

\section{Methods}

The process applied in the present work consisted of three main phases: biological treatment; advanced oxidation process (i.e. Fenton oxidation process); and Fentonbiological process, which itself consisted of two stages, including advanced oxidation process as stage I and biological treatment as stage II.

\section{Screening of dye degrader consortia}

The source of acclimated microorganisms was activated sludge from the secondary sedimentation basin of Nima Nassag Wastewater Treatment Plant, Tehran, Iran.

The mineral salt medium (MSM) contained the following (per liter): $6 \mathrm{~g} \mathrm{NaH}_{2} \mathrm{PO}_{4}, 3 \mathrm{~g} \mathrm{KH}_{2} \mathrm{PO}_{4}, 1 \mathrm{~g}$ $\mathrm{NH}_{4} \mathrm{Cl}, 0.5 \mathrm{~g} \mathrm{NaCl}$, and $1 \mathrm{~mL} 1 \mathrm{M} \mathrm{MgSO}_{4}$, all of which were of analytical grade. About $10 \mathrm{~g}$ of the sludge was added to $100 \mathrm{~mL}$ of MSM and put on the shaker at 150 $\mathrm{RPM}$ at $37^{\circ} \mathrm{C}$ for $12 \mathrm{~h}$. After allowing the sludge to settle down for $2 \mathrm{~h}$, the supernatant was inoculated to Luria Broth (LB) agar medium which contained the following (per liter): $10 \mathrm{~g}$ Casein enzymic hydrolyzate, $5 \mathrm{~g}$ yeast extract, $5 \mathrm{~g} \mathrm{NaCl}, 15 \mathrm{~g}$ agar, and $10 \mathrm{mg}$ RB5. The capable microorganisms of degrading dye were picked up on the basis of their ability to form clear zones on these plates. The colonies were transferred to LB agar slant for following experiments and identification. The isolated bacteria were detected on the basis of morphological, physiological, and biochemical characteristics according to Winn et. al (2006) [26].

\section{Biological treatment}

Experiments were performed in a $250 \mathrm{~mL}$ glass beaker containing $200 \mathrm{~mL}$ of LB media inoculated with a consortium of bacteria with an optical density of 0.1 at $600 \mathrm{~nm}$. Different concentrations of RB5 dye (50, 250, and $500 \mathrm{mg} / \mathrm{L}$ ) were added to the LB medium. To investigate the non-biological removal, the samples had similar blanks which were free of inoculation. In addition, to

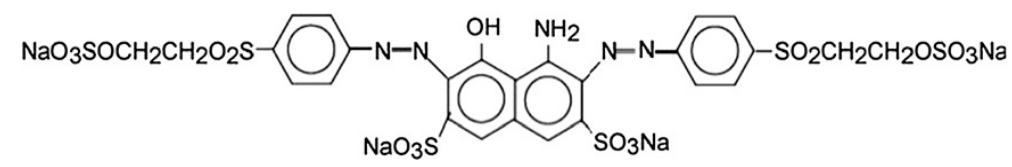

Figure 1 Chemical structure of the azo dye used in this study. 
investigate the adsorption by bacterial cell, killed controls were used too. A dye-free microbial blank was used to survey the changes in microbial population. All the reactors were incubated at $30 \pm 2^{\circ} \mathrm{C}$ in dark static conditions. At different time intervals, the samples were drawn and centrifuged at $6000 \mathrm{RPM}$ for $15 \mathrm{~min}$, and then the dye concentration was determined by a spectrophotometer at $600 \mathrm{~nm}$ [27].

\section{Optimization studies for decolorization of dye using Fenton reagent}

Optimization studies were carried out to optimize the time and low doses of $\mathrm{H}_{2} \mathrm{O}_{2}$ and $\mathrm{Fe}^{2+}$ ions for the decolorization of different concentrations of the RB5 dye. During the optimization for $\mathrm{pH}$ and time, doses of both $\mathrm{H}_{2} \mathrm{O}_{2}$ and $\mathrm{Fe}^{2+}$ ions were kept constant while $\mathrm{pH}$ and time were changed in the range of $2-8$ and 15$60 \mathrm{~min}$, respectively. The experiments were then conducted in a $250 \mathrm{~mL}$ glass beaker at the optimum time and $\mathrm{pH}$ applying different doses of $\mathrm{H}_{2} \mathrm{O}_{2}$ (i.e. 0.73, $1.47,2.2,2.9$, and $3.68 \mathrm{mM}$ ) and $\mathrm{Fe}^{2+}$ (i.e. $0.1,0.5,1$, and $2 \mathrm{mM}$ ) in 20 trials. The experiments were carried out in triplicate.

Dye solution was prepared by diluting the stock solution in distilled water, and the $\mathrm{pH}$ was adjusted by using $0.5 \mathrm{M} \mathrm{H}_{2} \mathrm{SO}_{4}$. A measured amount of $\mathrm{Fe}^{2+}$ ions and $\mathrm{H}_{2} \mathrm{O}_{2}$ were added to the reactor, and the reaction was allowed to continue for $15 \mathrm{~min}$ on an orbital shaker (200 RPM) at ambient temperature $\left(22-25^{\circ} \mathrm{C}\right)$. Afterwards, the supernatant was analyzed for color removal. In order to prevent any photo degradation, all the reactors were covered with foil.

\section{Fenton-biological treatment}

In stage I of the Fenton-biological process two levels of response were selected: high level (for the best removal) and low level (only for Fenton pretreatment and allowing for biological reaction). The first stage was similar to the Fenton oxidation process alone. Following the Fenton pretreatment, in stage II, pH of the sample was adjusted to 7 by using $1 \mathrm{M} \mathrm{NaOH}[28,29]$. Then, it was inoculated with a consortium of bacteria in LB with an optical density of 0.1 at $600 \mathrm{~nm}$ and kept at $30 \pm 2^{\circ} \mathrm{C}$ in dark condition; the samples were then drawn at different time intervals. All the experiments were carried out in triplicate.

\section{Analytical methods}

A CECIL-model $7100 \mathrm{UV} /$ vis spectrophotometer was used for monitoring the decolorization at $\lambda_{\max }=600 \mathrm{~nm}$ for RB5 [30]. The remained RB5 and its metabolites in the liquid was extracted with dichloromethane, which was then centrifuged (Hettich D7200) for $10 \mathrm{~min}$ at 6000 RPM. Degradation products were identified by comparing the retention time and fragmentation pattern, as well as based on the spectra in the GC-MS software.

The gas chromatography instrument comprised an Agilent (Centerville Road, Wilmington, USA) 7890A GC coupled with an Agilent MSD 5975C quadrupole mass spectrometer. The GC was fitted with HP-5 MS capillary column $(30 \mathrm{~m} \times 0.25 \mathrm{~mm}$ i.d., $0.25 \mu \mathrm{m}$ film thickness) from Agilent J\&W Scientific (Folsom, CA, USA). Helium (99.999\%) was used as the carrier gas at $1.0 \mathrm{ml} \mathrm{min}^{-1}$. The following temperature program was employed: $50^{\circ} \mathrm{C}$ for $1 \mathrm{~min}$, increased to $280^{\circ} \mathrm{C}$ at $10^{\circ} \mathrm{C} \mathrm{min}^{-1}$, and held for $5 \mathrm{~min}$. The MS quadruple and the MS source temperatures were set at 150 and $230^{\circ} \mathrm{C}$, respectively. Data acquisition was performed in the full scan mode $(\mathrm{m} / \mathrm{z}$ in the range of 50-550).

\section{Results}

Decolorization of different concentrations of dyes in biological treatment

The bacterial consortium was chosen on the basis of its ability to form a clear zone on the plate containing LB agar and RB5. To assess the maximum decolorization ability of the consortium, it was tested against different concentrations of the dye (Figure 2).

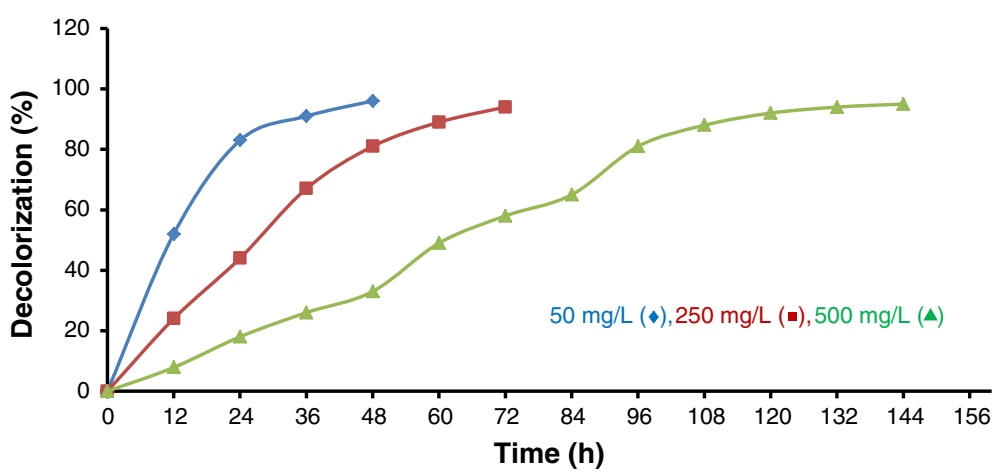

Figure 2 The percentage of RB5 decolorization at various initial dye concentrationsin the biological process. 
At a dye concentration of $50 \mathrm{mg} / \mathrm{L}$, more than $90 \%$ dye removal was achieved within $36 \mathrm{~h}$; similar decolorization was also observed at concentrations of 250 and $500 \mathrm{mg} / \mathrm{L}$ within 60 and $108 \mathrm{~h}$, respectively. The time required for complete decolorization of $50 \mathrm{mg} / \mathrm{L}$ of the dye was $48 \mathrm{~h}$, whereas it was $72 \mathrm{~h}$ for a dye concentration of $250 \mathrm{mg} / \mathrm{L}$. As concentration increased to $500 \mathrm{mg} / \mathrm{L}$, the time required for decolorization increased to $168 \mathrm{~h}$. Less than 3\% of the removal was related to the adsorption of dye on the cell mass (data are not shown).

\section{Decolorization of RB5 in Fenton process}

All the experiments were carried out at a dye concentration of $250 \mathrm{mg} / \mathrm{L}$. The influence of initial $\mathrm{pH}$ and time on the effectiveness of Fenton processes for RB5 degradation (expressed as color removal efficiency) is shown in Figure 3(a) and (b), respectively. The maximum dye removal was achieved at pH 3 in $15 \mathrm{~min}$; hence, the initial $\mathrm{pH}$ was kept constant at 3 for all other Fenton experiments, and the reactions were done in $15 \mathrm{~min}$. Figure 4 demonstrates the effect of iron and $\mathrm{H}_{2} \mathrm{O}_{2}$ concentrations on the dye removal. The RB5 removal increased by increasing concentrations Fenton reagents. Increasing of dye removal was significant by increasing $\mathrm{Fe}^{2+}$ from 0.1 to $0.5 \mathrm{mM}$.

\section{Decolorization of RB5 in combined process}

The time-course for the transformation of Fenton pretreated RB5 $(500 \mathrm{mg} / \mathrm{L})$ by the bacterial consortium is shown in Figure 5. The overall removal of more than $90 \%$ of RB5 was achieved in 36, 84, and $108 \mathrm{~h}$ for high and low levels of Fenton reagents and without pretreatment, respectively. Application of the Fenton pretreatment led to removal efficiencies of $28 \%$ and $74 \%$ for low and high levels of it, respectively.

\section{Discussion}

\section{Biological treatment}

The bacterial consortium, consisted of Alcaligenes Xylosoxidans and Alcaligenes Denitrificans, could completely decolorize RB5 when Casein enzymic hydrolysate and yeast extract were present in the medium. In the absence of yeast extract and Casein enzymic hydrolysate, the consortium did not have the ability to decolorize RB5. Moosvi et al. (2005) reported that an isolated bacterial consortium RVM 11.1 did not show decolorization when yeast extracts and glucose were omitted from the medium [31].

The decolorizing potential of the bacterial consortium was studied using RB5 at different initial concentrations in the range of $50-500 \mathrm{mg} / \mathrm{L}$. The rate of decolorization
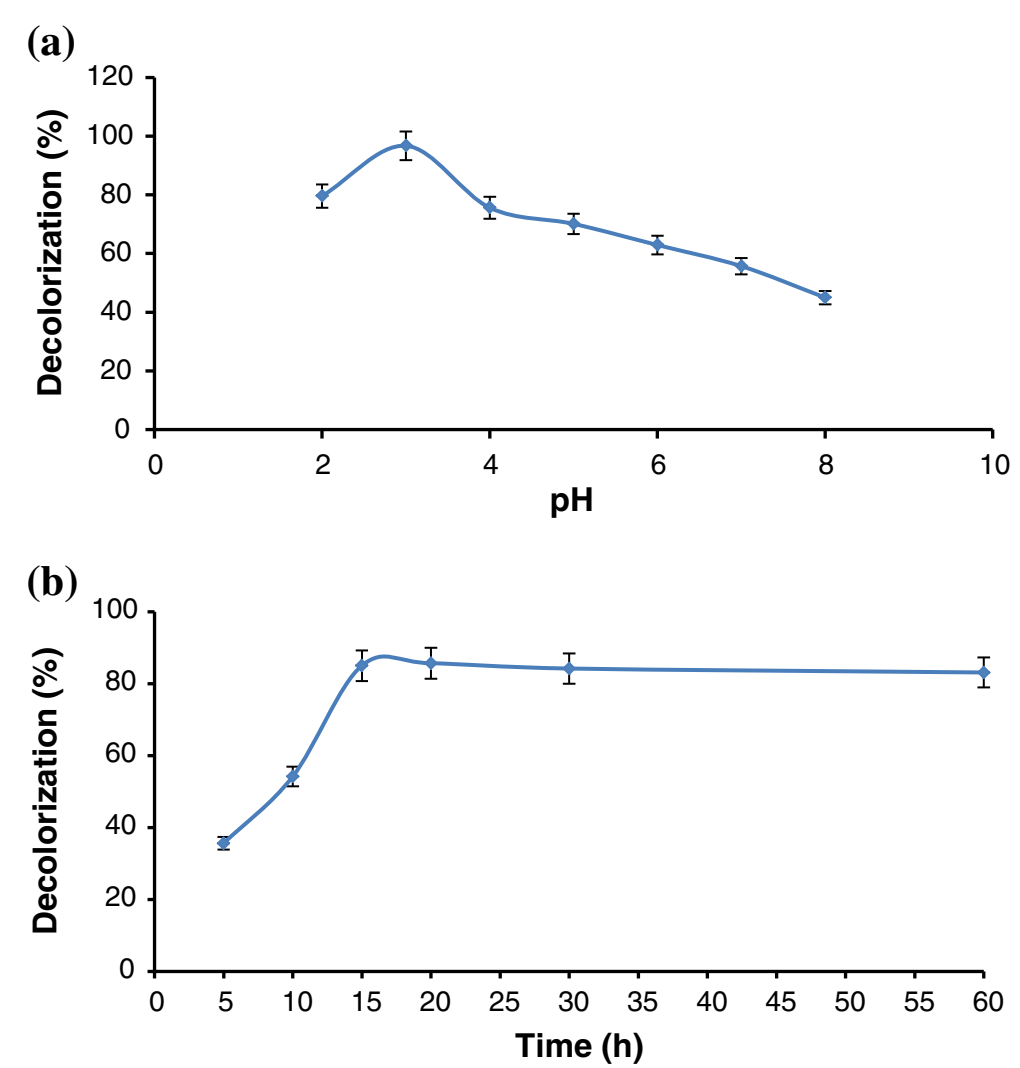

Figure 3 Effects of (a) initial pH and (b) reaction time on RB5 decolorization in the Fenton process (reaction conditions: initial dye concentration of $250 \mathrm{mg} / \mathrm{L} ; \mathrm{H}_{2} \mathrm{O}_{2}$ dose of $2.9 \mathrm{mM}$, and $\mathrm{Fe}^{2+}$ does of $0.5 \mathrm{mM}$ ). 


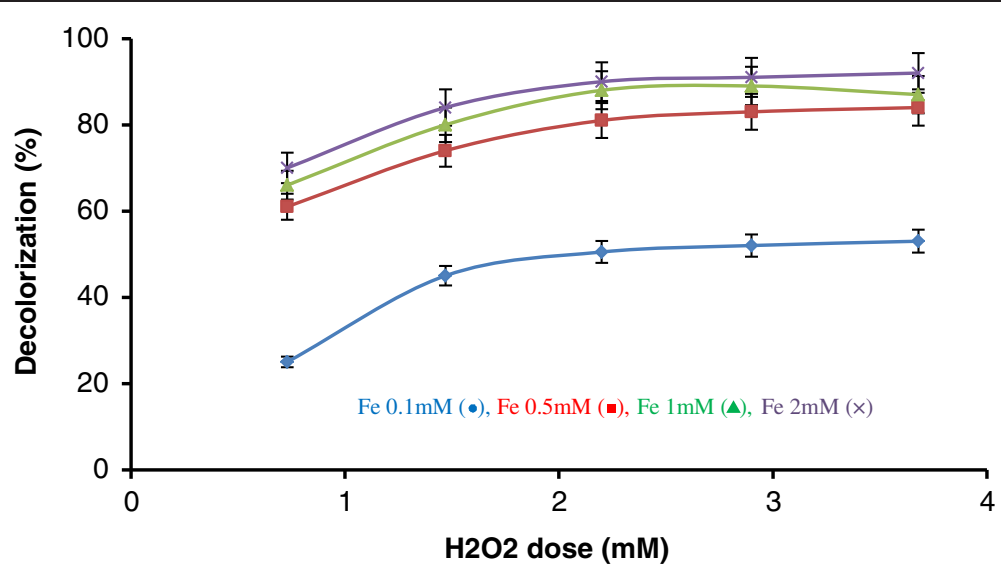

Figure 4 Effect of different concentrations of $\mathrm{H}_{2} \mathrm{O}_{2}$ and $\mathrm{Fe}^{2+}$ on $\mathrm{RB} 5$ decolorization in the Fenton process (experimental conditions: $[\mathrm{RB} 5]=250 \mathrm{mg} / \mathrm{L} ; \mathrm{pH}=3$; reaction time $=15 \mathrm{~min}$ ).

increased with an increase in the initial dye concentration. Similar observations have also been reported earlier for decolorization of RVM 11.1 up to $200 \mathrm{mg} / \mathrm{L}$ by Moosvi et al. (2005). However, they reported that further increase in the dye concentration resulted in the reduction of decolorization rates, while this led to a further increase of decolorization rates in our work [31]. The rate of RB5 removal by the bacterial consortium was about $0.9,2.1$, and $3.1 \mathrm{mg} / \mathrm{L} . \mathrm{h}$ for initial concentrations of 50, 250, and $500 \mathrm{mg} / \mathrm{L}$, respectively. Azo dyes generally contain one or more sulphonic-acid groups on aromatic rings, which might inhibit the growth of microorganisms and result in less biodegradation [3,32]; but using a mix culture of bacteria may result in higher levels of biodegradation, mainly because of their potential to overcome on decrease in their density. On the other hand, in the environment, the performance of dye removal by using a pure culture is not possible [1].

The time required for complete decolorization at a dye concentration of $50 \mathrm{mg} / \mathrm{L}$ was $60 \mathrm{~h}$, which was similar to that reported by Kalme et al. (2007). However, the time required for complete decolorization at dye concentrations of 250 and $500 \mathrm{mg} / \mathrm{L}$ was 4 and 7 days, respectively; this is better than the results observed by Kalme et al. (2007) [33]. These times required for biodegradation suggest that an acceptably high level of color removal cannot be achieved by biodegradation alone.

\section{Fenton treatment}

The effect of $\mathrm{pH}$ on the decolorization of RB5 by Fenton process is shown in Figure 3a. The experiments were carried out at $\mathrm{pH}$ values between 2 and 8 . The optimal $\mathrm{pH}$ values were obtained at $\mathrm{pH} 3$ with the highest decolorization of dye, which usually falls in the acidic range of $\mathrm{pH}$ in Fenton processes [34,35]. Under more alkaline conditions $(\mathrm{pH}>4)$, the precipitation of iron hydroxide occurs and the concentration of dissolved $\mathrm{Fe}^{3+}$ and, consequently, $\mathrm{Fe}^{2+}$ decreases. On the other hand, in this condition hydrogen peroxide is unstable and fewer hydroxyl radicals are formed, which may reduce the efficiency of the process [34]. It is noteworthy that for $\mathrm{pH}$

\section{(a)}

(b)

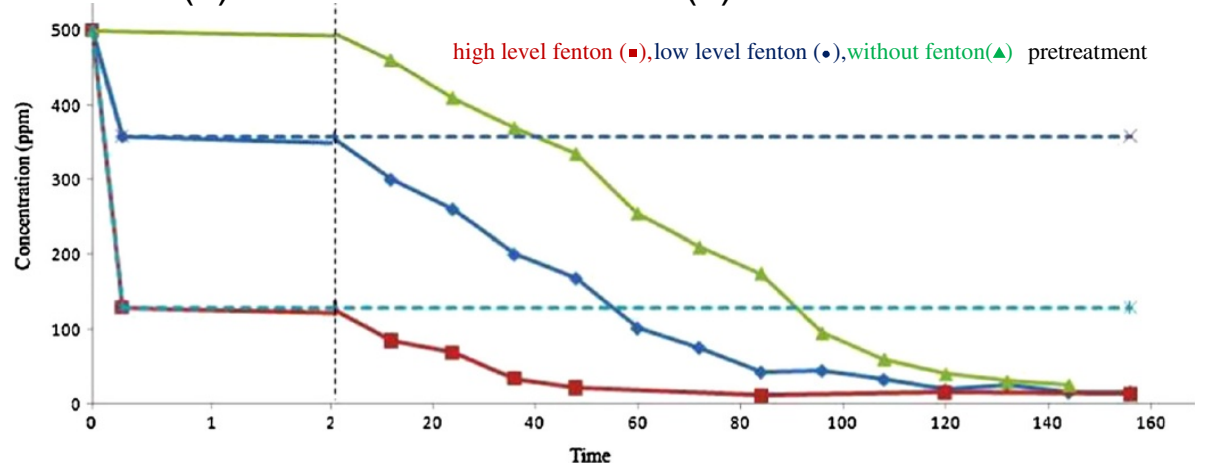

Figure 5 Biotransformation profile of RB5 treated with the combined Fenton-biological process; Fenton reagents with $\mathrm{Fe}^{2+}: \mathrm{H}_{2} \mathrm{O}_{2}$ molar ratio of 0.5:2.9 (a) in first $2 \mathrm{~h}$; (b) after $2 \mathrm{~h}$. 
values below 3, the reduction in the production of hydroxyl radical occurs too [35].

Figure $3 \mathrm{~b}$ indicated that the maximum dye removal was achieved at $15 \mathrm{~min}$ and color removal remained unaffected for the reaction times between 30 and $120 \mathrm{~min}$. High percents of dye removal were also obtained by Rodrigues et al. (2009) and Hsing et al. (2007) in less than $20 \mathrm{~min}[34,36]$.

In subsequent runs, consequently, the reaction time and the initial $\mathrm{pH}$ were kept constant at $15 \mathrm{~min}$ and 3, respectively. The concentration of hydrogen peroxide was the controlling factor for RB5 decolorization, which was consumed in the early stages of the reaction. As the $\mathrm{H}_{2} \mathrm{O}_{2}$ dosage was increased from 0.73 to $2.9 \mathrm{mM}$, the efficiency of RB5 decolorization increased up to $20-25 \%$ at $15 \mathrm{~min}$ of the reaction time. This indicates that the observed increase in the efficiency of RB5 decolorization was due to the increase in $\mathrm{OH} \cdot$ concentration by the addition of $\mathrm{H}_{2} \mathrm{O}_{2}$, as seen in Figure 4. However, further increase in hydrogen peroxide concentration, $\mathrm{H}_{2} \mathrm{O}_{2}$ > $2.9 \mathrm{mM}$,did not affect the degradation efficiency, which can be attributed to the scavenging effect of hydroxyl radical, according to Eq. 1 and 2:

$$
\begin{aligned}
& \mathrm{HO}^{\bullet}+\mathrm{H}_{2} \mathrm{O}_{2} \rightarrow \mathrm{H}_{2} \mathrm{O}+\mathrm{HO}_{2}^{\cdot} \\
& \mathrm{HO}_{2}^{\cdot}+\mathrm{HO}^{\bullet} \rightarrow \mathrm{H}_{2} \mathrm{O}+\mathrm{O}_{2}
\end{aligned}
$$

For different concentrations of different dyes, the optimum dose of $\mathrm{H}_{2} \mathrm{O}_{2}$ for dye degradation has been reported to be in the range of $0.73-72 \mathrm{mM}$ by Tantak et al. (2006), Lucas et al. (2006) and Hsing et al. (2007) $[4,35,36]$.

Degradation efficiency of dye was also influenced by the concentration of $\mathrm{Fe}^{2+}$ ions which catalyze hydrogen peroxide decomposition, resulting in the production of $\mathrm{OH}$ radicals and, consequently, degradation of the dye. With increasing doses of ferrous ions from 0.1 to $0.5 \mathrm{mM}$, the degradation efficiency of RB5 also increased up to $91.5 \%$. From this point forward, however, further addition of iron became inefficient. It can be seen from the results presented in Figure 4 that higher RB5 degradation levels were obtained with a lower $\mathrm{Fe}^{2+}$ concentration $(0.5 \mathrm{mM})$. Hsuing et al. (2007) reported a required $\mathrm{Fe}^{2+}$ dose of $8.93 \mathrm{mM}$ for the removal of Acid Orange 6 [36].

The optimal Fenton reagent ratio for RB5 degradation established on the basis of dye removal efficiency is $0.5 \mathrm{mM} \mathrm{Fe}^{2+}: 2.9 \mathrm{mM} \mathrm{H}_{2} \mathrm{O}_{2}$ at $\mathrm{pH} 3$, where the maximum dye removal efficiency of $91.5 \%$ was achieved. According to the previous studies, typical values of $\mathrm{Fe}^{2+} / \mathrm{H}_{2} \mathrm{O}_{2}$ are in the range of $1: 5$ to $1: 25$ [30]. Based on the results from the present work, dosesof $2.9 \mathrm{mM}$ of $\mathrm{H}_{2} \mathrm{O}_{2}$ and $0.5 \mathrm{mM}$ of $\mathrm{Fe}^{2+}$ were selected for conducting dye removal experiments by the combined Fenton-biotreatment process.

\section{Combining Fenton's reagent and biological treatment}

In this study, two processes, i.e. Fenton's reagents as a pretreatment followed by biological treatment including a bacterial consortium, were integrated for optimization purposes.

The major purpose of this integrated process was to reduce the treatment costs, particularly the hydrogen peroxide concentration used in the Fenton process for decolorizing a RB5 concentration of $500 \mathrm{mg} / \mathrm{L}$. It is noteworthy that during the Fenton pretreatment process, the reaction can also be carried out at a low ferrous ion dose; therefore, the amount of sludge generation would be negligible. This can solve the problem of sludge disposal, thereby adding to the cost-effectiveness of the process [19].

Two levels of high and low dose of Fenton's reagents of second phase results were selected for first stage. Then, the biodegradation of remaining RB5 and its metabolites were conducted by inoculating the bacterial consortium and incubating in static condition. At lower dose of Fenton's reagent the negative effect of $\mathrm{H}_{2} \mathrm{O}_{2}$ residual on the biological stage was minimized [19], mainly because of fast consumption of the oxidant [4,37-39]; on the other hand, there is no need for separating the precipitated iron oxides [40]. High dose of Fenton's reagent was used for the highest effect on color removal.

Results indicated that a significant reduction in the biological detention time was achieved (Figure 5). Biological treatment as a single process could achieve an acceptable reduction at an initial dye concentration of $500 \mathrm{mg} / \mathrm{L}$ after about 6 days. However, in the combined Fentonbiotreatment system could achieve a removal efficiency of about $90 \%$ in almost 3 days, which is considered to be more cost-effective because shorter HRTs decrease the installation costs.

The GC-MS spectrum showed various peaks indicating the partial mineralization of RB5 after the Fenton process (Figure 6a). The retention time of peaks and suggested MW indicated that in the Fenton process, RB5 was most likely broken down into compounds with lower MW.It also suggested that decolorization was related to the breaking of azo bonds which are associated with chromophores, i.e. conjugated unsaturated bonds $(-\mathrm{N}=\mathrm{N}-)$ in the molecule $[15,41]$. In this stage, some aromatic amines intermediates, such as Aniline and 1Aminonaphthalene, may have been produced, indicating partial mineralization of RB5. The production of aromatic amines is in agreement with the results from the study of Kang et al. (2000) (Kang et al. 2000) , which are still health hazards [4]. However, Azbar et al. (2004) reported that complete dearomatization of dye is associated with AOP process [42]. The cleavage of azo bonds and formation of aromatic amines with the amines which are linked to the dyes are also reported by Janakar et al. (2006) [43]. 


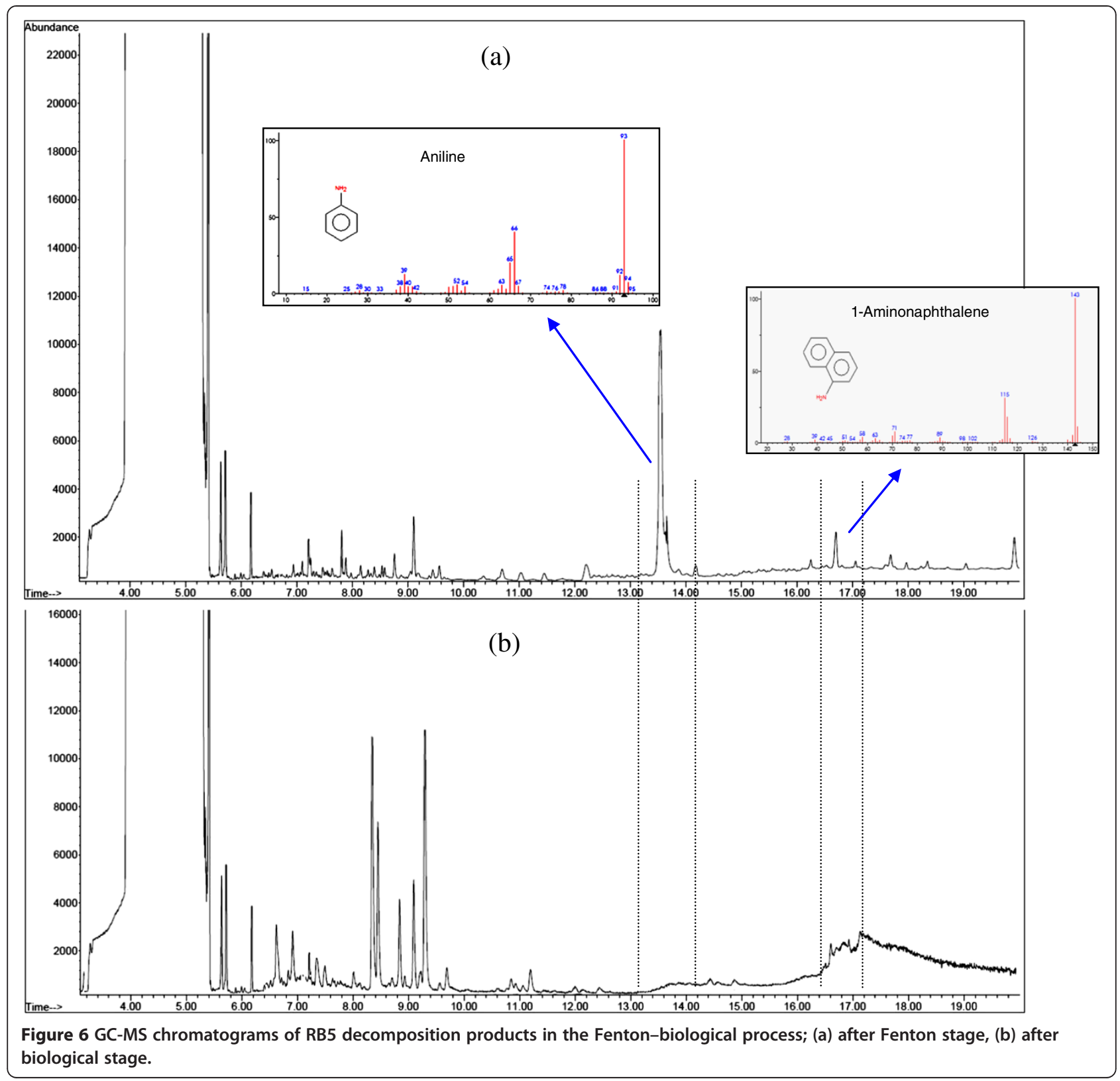

The results of GC-MS analysis of the effluents treated by the Fenton-biological process showed a significant reduction in aromatic amines (Figure 6a). Decreasing in peaks implies the progress in the mineralization of RB5 and its metabolites. Therefore, dearomatization occurs in the biological stage. Our results demonstrated positive effects of inoculating bacterial consortium which was capable of dye biodegradation with a Fenton's pretreatment step as well as the benefits of low time required for the biological process.

\section{Conclusions}

Two stages, i.e. Fenton oxidation and anoxic biological treatment, were integrated with the purpose of reducing the treatment costs via less need for oxidant and catalyst and reduced sludge production. In the biological process alone, decolorization rate increased by increasing the initial dye concentration; the decolorization rate was $3.1 \mathrm{mg} / \mathrm{L} . \mathrm{h}$ for an initial RB5 concentration of $500 \mathrm{mg} / \mathrm{L}$. In the Fenton oxidation process alone, the optimum conditions to obtain the highest decolorization rate were: $0.5 \mathrm{mM} \mathrm{Fe}^{2+}, 2.9 \mathrm{mM} \mathrm{H}_{2} \mathrm{O}_{2}, \mathrm{pH} \mathrm{3}$, and a detention time of $15 \mathrm{~min}$. After Fenton oxidation process, some aromatic amines intermediates were produced, suggesting that partial mineralization occurred in the process.

In the combined Fenton-biological process, lower doses of Fenton's reagents were used to have the minimum negative effect of $\mathrm{H}_{2} \mathrm{O}_{2}$ residual on the biological 
stage. In this stage, the retention time reduced to half of that needed for biological treatment alone; significant reductions also occurred in the concentration of aromatic amines intermediates. Our results indicated that Fenton oxidation process combined with anoxic biological process is a cost-effective method for dye decolorization as well as for dearomatization of aromatic amines intermediates.

\section{Competing interests}

The authors declare that they have no competing interests.

\section{Authors' contributions}

Pegah Bahmani, Roshanak Rezaei Kalantary, Ali Esrafili, Mitra Gholami and Ahmad Jonidi Jafari carried out the article with the title of: Evaluation of Fenton oxidation process coupled with biological treatment for the removal of reactive black 5 from aqueous solution, participated in the sequence alignment and drafted the manuscript. All authors read and approved the final manuscript.

\section{Acknowledgements}

This research was conducted with funding from the vice chancellor for research of Tehran University of medical sciences.

\section{Author details}

'Department of Environmental Health Engineering, School of Public Health, Tehran University of Medical Sciences, Tehran, Iran. ${ }^{2}$ Center for Water Quality Research (CWQR), Institute for Environmental Research (IER), Tehran University of Medical Sciences, Tehran, Iran. ${ }^{3}$ Department of Environmental Health Engineering, School of Medical Sciences, TarbiatModaresUniversity, Tehran, Iran

Received: 17 January 2013 Accepted: 19 June 2013

Published: 28 June 2013

\section{References}

1. Dafale N, Wate S, Meshram S, Nandy T: Kinetic study approach of remazol black-B use for the development of two-stage anoxic-oxic reactor for decolorization/biodegradation of azo dyes by activated bacterial consortium. J Hazard Mater 2008, 159(2-3):319-328.

2. Soloman PA, Basha CA, Velan M, Ramamurthi V, Koteeswaran K, Balasubramanian N: Electrochemical Degradation of Remazol Black B Dye Effluent. Clean Soil Air Water 2009, 37(11):889-900.

3. Kalyani DC, Telke AA, Dhanve RS, Jadhav JP: Ecofriendly biodegradation and detoxification of reactive red 2 textile dye by newly isolated pseudomonas sp. SUK1.J Hazard Mater 2009, 163(2-3):735-742.

4. Tantak NP, Chaudhari S: Degradation of azo dyes by sequential Fenton's oxidation and aerobic biological treatment. J Hazard Mater 2006, 136(3):698-705.

5. Jin X-C, Liu G-Q, Xu Z-H, Tao W-Y: Decolorization of a dye industry effluent by Aspergillus fumigatus XC6. Appl Microbiol Biot 2007, 74(1):239-243.

6. Zhao X, Hardin IR: HPLC and spectrophotometric analysis of biodegradation of azo dyes by Pleurotus ostreatus. Dye Pigment 2007, 73(3):322-325

7. Çinar Ö, Demiröz K, Kanat G, Uysal Y, Yaman C: The effect of oxygen on anaerobic color removal of azo dye in a sequencing batch reactor. Clean Soil Air Water 2009, 37(8):657-662.

8. Chang J-S, Lin C-Y: Decolorization kinetics of a recombinant escherichia coli strain harboring azo-dye-decolorizing determinants from Rhodococcus sp. Biotechnol Lett 2001, 23(8):631-636.

9. Liu G-f, Zhou J-t, Wang J, Song Z-y, Qv Y-y: Bacterial decolorization of azo dyes by rhodopseudomonas palustris. World J Microb Biot 2006, 22(10):1069-1074.

10. Zeroual Y, Kim B, Yang M, Blaghen M, Lee K: Decolorization of some azo dyes by immobilized \&lt;i\&gt; geotrichum sp. biomass in fluidized bed bioreactor. Appl Biochem Biot 2007, 142(3):307-316.

11. Dalvand A, Gholami M, Joneidi A, Mahmoodi NM: Dye removal, energy consumption and operating cost of electrocoagulation of textile wastewater as a clean process. Clean Soil Air Water 2011, 39(7):665-672.
12. Mohana S, Shrivastava S, Divecha J, Madamwar D: Response surface methodology for optimization of medium for decolorization of textile dye Direct Black 22 by a novel bacterial consortium. Bioresource Technol 2008, 99(3):562-569.

13. Supaka N, Juntongjin K, Damronglerd S, Delia M-L, Strehaiano P: Microbial decolorization of reactive azo dyes in a sequential anaerobic-aerobic system. Chem Eng J 2004, 99(2):169-176.

14. Al-Degs Y, Khraisheh MAM, Allen SJ, Ahmad MN: Effect of carbon surface chemistry on the removal of reactive dyes from textile effluent. Water Res 2000, 34(3):927-935.

15. Meriç S, Kaptan D, Ölmez T: Color and COD removal from wastewater containing reactive black 5 using Fenton's oxidation process. Chemosphere 2004, 54(3):435-441.

16. Lin SH: Adsorption of disperse dye by powdered activated carbon. J Chem Technol Biot 1993, 57(4):387-391.

17. Kusvuran E, Gulnaz O, Irmak S, Atanur OM, Ibrahim Yavuz H, Erbatur O: Comparison of several advanced oxidation processes for the decolorization of reactive red 120 azo dye in aqueous solution. $J$ Hazard Mater 2004, 109(1-3):85-93.

18. Kalyani DC, Patil PS, Jadhav JP, Govindwar SP: Biodegradation of reactive textile dye red BLI by an isolated bacterium pseudomonas sp. SUK1. Bioresour Technol 2008, 99(11):4635-4641.

19. Lodha B, Chaudhari S: Optimization of fenton-biological treatment scheme for the treatment of aqueous dye solutions. J Hazard Mater 2007, 148(1-2):459-466.

20. Kotsou M, Kyriacou A, Lasaridi K, Pilidis G: Integrated aerobic biological treatment and chemical oxidation with Fenton's reagent for the processing of green table olive wastewater. Process Biochem 2004 39(11):1653-1660.

21. Al Momani FGO, Sans C, Esplugas S: Combining photo-Fenton process with biological sequencing batch reactor for 2,4-dichlorophenol degradation. Water Sci Technol 2004, 49(4):293-298.

22. Garcia-Montano JTF, Garcla-Hortal JA, Domenech X, Peral J: Degradation of Procion Red H-E7B reactive dye by coupling a photo-Fenton system with a sequencing batch reactor. J Hazard Mater 2006, 134(1-3):220-229.

23. Ledakowicz S, Solecka M, Zylla R: Biodegradation, decolourisation and detoxification of textile wastewater enhanced by advanced oxidation processes. J Biot 2001, 89(2-3):175-184.

24. Neamtu M, Yediler A, Siminiceanu I, Macoveanu M, Kettrup A: Decolorization of disperse red 354 azo dye in water by several oxidation processes-a comparative study. Dye Pigment 2004, 60(1):61-68.

25. Lucas MS, Dias AA, Sampaio A, Amaral C, Peres JA: Degradation of a textile reactive Azo dye by a combined chemical-biological process: Fenton's reagent-yeast. Water Res 2007, 41(5):1103-1109.

26. Koneman EW: Koneman's Color Atlas and Textbook of Diagnostic Microbiology (Color Atlas \& Textbook of Diagnostic Microbiology). Baltimore: Lippincott Williams \& Wilkins; 2006.

27. Kumar K, Devi SS, Krishnamurthi K, Dutta D, Chakrabarti T: Decolorisation and detoxification of direct blue-15 by a bacterial consortium. Bioresource Technol 2007, 98(16):3168-3171.

28. Lin SH, Lo CC: Fenton process for treatment of desizing wastewater. Water Res 1997, 31(8):2050-2056.

29. Fongsatitkul $P$, Elefsiniotis $P$, Yamasmit $A$, Yamasmit $N$ : Use of sequencing batch reactors and Fenton's reagent to treat a wastewater from a textile industry. Biochem Eng J 2004, 21(3):213-220.

30. KN KH_caric'AL: Fenton type processes for minimization of organic content in coloured wastewaters: Part I: processes optimization. Dye Pigment 2007, 74:380-387.

31. Moosvi S, Keharia H, Madamwar D: Decolourization of textile dye reactive violet 5 by a newly isolated bacterial consortium RVM 11.1. World $J$ Microb Biot 2005, 21(5):667-672.

32. Chen K-C, Wu J-Y, Liou D-J, Hwang S-CJ: Decolorization of the textile dyes by newly isolated bacterial strains. J Biot 2003, 101(1):57-68.

33. Kalme SD, Parshetti GK, Jadhav SU, Govindwar SP: Biodegradation of benzidine based dye direct blue- 6 by pseudomonas desmolyticum NCIM 2112. Bioresource Technol 2007, 98(7):1405-1410.

34. Rodrigues CSML, Boaventura RA: Optimization of the azo dye procion red H-EXL degradation by Fenton's reagent using experimental design. J Hazard Mater 2009, 164(2-3):987-994.

35. Lucas MS, Peres JA: Decolorization of the azo dye reactive black 5 by Fenton and photo-Fenton oxidation. Dye Pigment 2006, 71(3):236-244. 
36. Hsing $\mathrm{H}-\mathrm{J}$, Chiang P-C, Chang EE, Chen M-Y: The decolorization and mineralization of acid orange 6 azo dye in aqueous solution by advanced oxidation processes: a comparative study. J Hazard Mater 2007, 141(1):8-16.

37. Ramirez JH, Costa CA, Madeira LM: Experimental design to optimize the degradation of the synthetic dye Orange II using Fenton's reagent. Catal Today 2005, 107-108:68-76.

38. Malik PK, Saha SK: Oxidation of direct dyes with hydrogen peroxide using ferrous ion as catalyst. Sep Purif Technol 2003, 31(3):241-250.

39. Arslan-Alaton I, Gursoy BH, Schmidt J-E: Advanced oxidation of acid and reactive dyes: effect of Fenton treatment on aerobic, anoxic and anaerobic processes. Dye Pigment 2008, 78(2):117-130.

40. García-Montaño J, Pérez-Estrada L, Oller I, Maldonado MI, Torrades F, Peral J: Pilot plant scale reactive dyes degradation by solar photo-Fenton and biological processes. J Photoch Photobio A 2008, 195(2-3):205-214.

41. Muruganandham $M$, Swaminathan M: Decolourisation of reactive orange 4 by Fenton and photo-Fenton oxidation technology. Dye Pigment 2004, 63(3):315-321.

42. Azbar N, Yonar T, Kestioglu K: Comparison of various advanced oxidation processes and chemical treatment methods for COD and color removal from a polyester and acetate fiber dyeing effluent. Chemosphere 2004, 55(1):35-43.

43. Junnarkar N, Murty D, Bhatt N, Madamwar D: Decolorization of diazo dye direct red 81 by a novel bacterial consortium. World J Microb Biot 2006, 22(2):163-168.

doi:10.1186/2052-336X-11-13

Cite this article as: Bahmani et al:: Evaluation of Fenton oxidation process coupled with biological treatment for the removal of reactive black 5 from aqueous solution. Journal of Environmental Health Sciences \& Engineering 2013 11:13.

\section{Submit your next manuscript to BioMed Central and take full advantage of:}

- Convenient online submission

- Thorough peer review

- No space constraints or color figure charges

- Immediate publication on acceptance

- Inclusion in PubMed, CAS, Scopus and Google Scholar

- Research which is freely available for redistribution 